\title{
Opportunity Costs of REDD+ to the Communities of Mufindi District, Iringa, Tanzania
}

\author{
Faraji Nuru, ${ }^{1}$ Jumanne Moshi Abdallah, ${ }^{2}$ and Yonika Mathew Ngaga ${ }^{2}$ \\ ${ }^{1}$ Tanzania Forestry Research Institute, P.O. Box 1854, Morogoro, Tanzania \\ ${ }^{2}$ Sokoine University of Agriculture, P.O. Box 3011, Morogoro, Tanzania \\ Correspondence should be addressed to Faraji Nuru; sighefaranuru@yahoo.com
}

Received 17 July 2013; Revised 31 January 2014; Accepted 31 January 2014; Published 5 March 2014

Academic Editor: Piermaria Corona

Copyright (c) 2014 Faraji Nuru et al. This is an open access article distributed under the Creative Commons Attribution License, which permits unrestricted use, distribution, and reproduction in any medium, provided the original work is properly cited.

\begin{abstract}
The study was done to assess the opportunity costs of REDD+ to the communities of Mufindi District which is located in the Southern Highlands of Tanzania. The specific objectives were, to identify and assess the economic value of alternative land uses, the aboveground carbon stock of Idewa Forest Reserve (IFR), and the profitability of each land use as compared to REDD+ incentives. Data were collected using questionnaire survey, key informant interview, and forest inventory and data were analyzed using the Excel programme. Results showed that the main land uses were agriculture and tree planting with economic values of $\$ 2958.52$ and $\$ 3272.94$ per ha per year, respectively. The total aboveground carbon was $39.23 \mathrm{t} / \mathrm{ha}$ (143.97/ha). The opportunity costs of REDD+ was varying depending on the price per ton of carbon. The opportunity costs of REDD+ will be profitable if the price per $\mathrm{tCO}_{2} \mathrm{e}$ will be at least $\$ 23$. It can therefore be concluded that there is no general unit price per ton of carbon dioxide equivalent $\left(\mathrm{tCO}_{2} \mathrm{e}\right)$, as it depends on REDD+ opportunity cost when compared with alternative land uses within a particular place. Therefore we recommend opportunity costs of REDD+ to communities be used to guide decision making on unit prices of carbon.
\end{abstract}

\section{Introduction}

Reducing emissions from deforestation and forest degradation (REDD) was recognized officially at the 2007 CoP13 in Bali. In 2005, discussions focused only on "reducing emissions from deforestation" (RED). As it became clear that forest degradation in some countries was an even bigger problem than deforestation, "avoided degradation" (the second D) was officially endorsed at the 2007 COP13 in Bali and RED morphed into "reducing emissions from deforestation and degradation" (REDD). Subsequently, it was further recognized that there could be climate benefits not only from avoiding negative changes (deforestation, degradation) but also from enhancing positive changes, such as conserving and restoring forests [1]. This can be referred to as "removals" or "negative emissions." It was expressed as the "+," and "reducing emissions from deforestation and forest degradation in developing countries (REDD); and the role of conservation, sustainable management of forests and enhancement of forest carbon stocks in developing countries" (REDD+) became official language at the 2008 COP14 in Poznan [2].

A core idea underlying REDD+ is to make performancebased payments, that is, to pay forest owners and users to reduce emissions and increase carbon sequestration. Regardless of whether or not individuals or communities are being compensated financially if REDD+ limits their livelihoods (legal or not) benefits/opportunities, then they bear an opportunity cost. If these costs are not compensated in some way (financially or otherwise), there are two implications: (1) pressure on forest utilization will continue or (2) the opportunity cost would cause harm to communities, in violation of international good practice standards (and World Bank safeguards) of "doing no harm" [2].

Deforestation and forest degradation, through agricultural expansion, conversion to pastureland, infrastructure development, destructive logging, fires, and so forth, accounts for nearly $20 \%$ of global greenhouse gas (GHG) 
emissions [3]. Reducing deforestation and degradation conserves carbon and other benefits that forests provide. But it foregoes the benefits of alternative land uses, such as crop and livestock production. These foregone benefits, or opportunity costs, are very significant components of the costs of REDD+.

Other costs include costs for implementation and administration, sociocultural and transaction costs, stabilization, and indirect costs [4]. The basic idea of REDD+ is to generate a significant level of compensation or economic incentive to outweigh the income generated through deforestation [5] among which is to compensate for the opportunity costs that communities incur from alternative land uses such as agriculture and livestock keeping. Since REDD+ is an emerging issue all over the world, there is limited information on its opportunity costs to different communities especially those living adjacent to the forests in developing countries.

Participatory Forest Management (PFM) is among the strategies for REDD+ implementation in various countries including Tanzania where local communities are involved. Majority of nongovernment organizations (NGOs) in Tanzania are using PFM to implement REDD+. Under PFM local communities and the government comanage forest reserves through Joint Forest Management (JFM) where the owner of the forest is either central government or local government and Community-Based Forest Management (CBFM) where local communities are the owner of the forest. The involvement of local communities in forest management in the country follows substantial reforms that have taken place in the forest sector within the past few years, following the adoption of the National Forest Policy [6] and implementation of the Forest Act in 2002 [7].

Mufindi is one of the five districts in Iringa Region implementing PFM under both JFM and CBFM. The implementation of PFM is the one which made this study done in Mufindi District so as to determine whether the coming REDD+ initiatives will be effective because currently there is no study which has already been done in this area to assess the opportunity costs of REDD+ to the communities.

The results of this study help clarify how to design an appropriate financial or policy incentive to change behavior at ground level. Prospective studies are needed as future opportunity costs will depend on REDD+ incentives and land-use incentives, price, and so forth [8].

The main objective of this study was to assess the opportunity costs of REDD+ to the communities of Mufindi District. We assessed the economic value of alternative land use, aboveground carbon stock at Idewa Forest Reserve managed under PFM, and the profitability of each land use as compared to REDD+ incentives.

\section{Methodology}

2.1. Description of the Study Area. The study was carried out in Mufindi District in Iringa Region. Mufindi District is one of the seven districts in Iringa Region located in Southern Highland of Tanzania. It is among the five districts in Iringa Region implementing PFM under both Joint Forest
Management (JFM) and Community-Based Forest Management (CBFM).

Mufindi District lies between latitude $8^{\circ} .00^{\prime}-9^{\circ} .15^{\prime}$ south and longitude $34^{\circ} 35^{\prime}-35^{\circ} 55^{\prime}$ east. The district is bordered by Iringa Rural District to the north, Morogoro Region to the east, Njombe District to the south, and Mbeya Region to the west. It is situated about $80 \mathrm{~km}$ from Iringa Municipality and boarders Kilolo to the north east and Kilombero to the south east. Mufindi District is characterized by two idiosyncratic features, specifically the Eastern Highlands and the Mufindi Plateau. The Eastern Highlands lie at an altitude of 1700$2200 \mathrm{~m}$ above sea level. The mean annual rainfall ranges between 1200 and $1600 \mathrm{~mm}$. The average precipitation is $1400 \mathrm{~mm}$ per annum where by the east and south are the wetter parts while the west is much drier. Temperatures are often below $15^{\circ} \mathrm{C}$ and the mean monthly is $18.4^{\circ} \mathrm{C}$ (maxima, November and February) and the minima is $13.2^{\circ} \mathrm{C}$ (July). Vegetation includes low/shrub land and scattered forests.

Mufindi plateau is extensive and uniform covering halfway of Iringa rural through Mafinga up to Makambako. Its altitude ranges from 1700 to $2000 \mathrm{~m}$ above sea level. The average mean annual rainfall is $950 \mathrm{~mm}$. In the eastern part of the plateau the annual rainfall is slightly higher than $950 \mathrm{~mm}$. The average evapotranspiration is $1300 \mathrm{~mm}$ per annum, whereas the maximum temperature is $18.3^{\circ} \mathrm{C}$ (February) and the minimum is $13.1^{\circ} \mathrm{C}$ (July).

2.2. Data Collection. For estimation of above ground carbon a total of 44 temporary circular sample plots of radius $15 \mathrm{~m}$ ( $0.07 \mathrm{ha})$ were established randomly throughout the forest. The distance between plots was varying between $100 \mathrm{~m}$ and $200 \mathrm{~m}$. All trees with $\mathrm{DBH} \geq 6 \mathrm{~cm}$ within each sample plot were measured for diameter at breast height (dbh). Heights for the largest, medium, and smallest trees were also measured.

In order to determine costs and benefits of alternative land uses, household was the sampling units for the study. Two villages, namely, Kibengu and Ilogombe, were sampled purposively based on their closeness to Idewa Forest Reserve, whereby 30 households in each village were randomly interviewed. According to Bailey [19] a subsample size of 30 from one observation unit is considered adequate provided that characteristics of the study population were well excluded. The sampling frame at Kibengu and Ilogombe villages was 580 and 395 households, respectively. Questionnaire survey and key informant interview methods were main tools used to collect data for costs and benefits of alternative land uses. Key informants here were District Natural Resources officer and small scale farmers.

2.3. Data Analysis. The above ground carbon was obtained as a product of tree volume, average wood basic density, and biomass carbon conversion factor 0.49 [20, 21].

The basal area was calculated from measured stems diameter at breast height $(1.3 \mathrm{~m})$ for all trees in each plot. The calculated basal area, trees heights, and the form factor were then used to calculate tee volume. The form factor of 0.5 for natural forest [22] was used. Heights for all trees were 
obtained by regressing diameters and the heights of measured sample trees to get the height-dbh relationship.

The trees volume was computed as a product of basal area, height, and the form factor.

The amount of carbon obtained in grams was then converted to tones of carbon per hectare (tC/ha) of carbon. Thereafter the computed amount of carbon was multiplied by the suggested prices of carbon per hectare to get the economic value of the forest for opportunity cost determination.

Microsoft Excel computer program was used to analyze the economic data to obtain the net annual profit and then the NPV. Potential financial profitability was calculated for each of the important land uses identified. The profitability analysis considered all establishment costs and all cost and revenue streams over the lifetime (in this study it is 20 years) of the production systems. The net profit obtained by subtracting total costs from the total revenue for each item was discounted and summed to produce an estimate of the net present value (NPV).

The major assumptions introduced at the stage of NPV calculation were the discount rate $(r)$ and the time horizon (T).

All labour is valued at the local market wage and outputs valued by farm-level prices. The analysis used a discount rate of $10 \%$. From a national perspective, the discount rate can be equated to the cost of borrowing money. The interest rate on loans (often between 5 and $10 \%$ annually) is a useful proxy [23]. A 20-year time horizon was used with assumption that REDD+ will be implemented for 20 years. The length of the time horizon for analysis can be an arbitrary decision yet should be guided by REDD+ policy. Common horizons range from 20 to 50 years, and perhaps more [23]. For discount rates, NPV analyses typically use loan interest rates which are set by a national bank or the government. Such rates can range from 10 to $30 \%$. Although agricultural loans are rarely available, especially in remote forest margin regions, bank interest rates do serve as a good indicator of the time value of money [23].

\section{Results and Discussion}

3.1. The Economic Value of Alternative Land Uses. In the study area, the crops grown include maize, beans, peas, Irish potatoes, and pyrethrum whereby maize and beans are the main crops. Apart from crop cultivation respondents in the study area were also involving tree planting activities and every household had an area of at least 0.2 ha of trees. The main species preferred was Pinus patula. The economic value of each of the main crops cultivated and trees was as discussed below.

\subsection{The Economic Value of Maize and Beans. Maize and} beans were the main crops cultivated in the two study villages, Kibengu and Ilogombe. They all involve similar stages of management which are land preparation, planting, weeding, and harvesting. Normally households in the study villages use family members for all farm activities so the costs for the farming activities were taken basing on those few farmers who use casual labours. The costs for land preparation differs in the two villages; at Kibengu it was varying between TZS 74,100 and TZS 123,500 per ha while at Ilogombe it was TZS 98,800 per ha. Weeding cost was varying between TZS 49,400 and TZS 74,100 per ha at Ilogombe and at Kibengu village it was TZS 74,100 per ha. These costs are equal TZS 3,000 per man day where it takes seventeen to twenty man days/ha and 24 man days/ha for weeding and digging, respectively. This is underpayment if compared to the current value of the Tanzanian shilling. The minimum government payment per man day for the financial year 2011/2012 was TZS 5,192. Households used to recycle seeds used in the last season. This was a practice for both maize and beans. Fertilizer application in the study area was not common for all villages; some use fertilizers and others do not depending on their economy and access. Prices for fertilizers depended on the type of fertilizer and whether the fertilizers were subsidized or not. Fertilizer like NPK (nitrogen-phosphate-potassium compound fertilizer) which is used for planting was TZS $47,000 / 50 \mathrm{~kg}$ with subsidy and TZS 70,000 to $90,000 / 50 \mathrm{~kg}$ without subsidy and for growth enhancing fertilizers like DAP (diammonium phosphate) it was TZS 25000 up to TZS 50,000 depending on whether it is subsidized or not.

Results show that the average production of maize for Kibengu and Ilogombe was about 140 bags (20 kg per bag) and 94 bags per ha per season, respectively. Beans production per ha per season was about 44 bags and 57 bags, respectively. The amount of fertilizer per pit was also varying from one farmer to another. These might be the reason for the big difference in productivity per ha between farmers. Other reasons may be due to exhaustion of soils in farms and lack of records by farmers which might lead to information which may be different from the reality. The farm size per household was varying depending on the type of crop produced. Mnenwa and Maliti [24] have also reported that the size of cultivated land varied greatly by farming system. For maize production the sample households cultivate between 0.3 ha and 1.2 ha while for beans production they cultivate between 0.1 ha and 1.2 ha per household. The study carried by Mnenwa and Maliti [24] revealed that most households (67\%) in Tanzania owned between zero and two acres (0.8 ha) of cultivated land. This implies that farm size per household was small and it might be due to the use of hand hoe for cultivation which consumes a lot of energy. The data on farm size also confirm the land pressure constraint especially in the subhumid uplands and for the poor [25].

The profitability of agriculture in the study area was estimated by calculating the NPV of the main crops cultivated by the villagers. The average undiscounted profit for maize and beans at Kibengu village was TZS 416,915.42/ha and TZS 641,925.56/ha, respectively. At Ilogombe, the average undiscounted net profit was TZS 184,049.83/ha and TZS $732,450.00 /$ ha for maize and beans, respectively. These results were then discounted to obtain NPV for the twenty-year time horizon for maize and beans (Table 1).

3.3. Woodlots. All respondents (100\%) in the study area own woodlots. The size of the woodlot per household was varying 
TABLE 1: Profitability of maize and beans farming Kibengu and Ilogombe villages.

\begin{tabular}{lccc}
\hline Village & Product & Undiscounted net profit/ha & NPV/ha (20 years) \\
\hline Kibengu & Maize & $416,915.42$ & $3,966,351.39$ \\
Ilogombe & Maize & $184,049.83$ & $1,0,969.81$ \\
Kibengu & Beans & $641,925.56$ & $6,106,999.67$ \\
Ilogombe & Beans & $732,450.00$ & $6,968,209.75$ \\
\hline Weighted average profit & & $493,835.20$ & $4,698,132.66$ \\
\hline
\end{tabular}

TABLE 2: Profitability of woodlots establishment at Kibengu and Iligombe villages.

\begin{tabular}{lccc}
\hline Village & Product & Undiscounted net profit (TZS)/ha & NPV/ha \\
\hline Kibengu & Pinus patula & $586,095.70$ & $5,575,858.92$ \\
Ilogombe & Pinus patula & $506,539.99$ & $4,819,000.58$ \\
\hline Total & & $1,092,635.70$ & $10,394,859.50$ \\
Weighted average profit & & $546,317.86$ & $5,197,429.75$ \\
\hline
\end{tabular}

Source: field data (2012).

between 0.2 ha and 1.2 ha at Ilogombe and between 0.4 ha and 3.24 ha at Kibengu village. Malimbwi [22] also reported that woodlots in the Southern high lands of Tanzania range from 0.25 to 3 hectares per household. Most of the households in the study area use family members to manage the woodlots. These include land preparation, planting, and pruning.

In the study area, many of the silvicultural activities were carried out by household members; therefore it was difficult to predict the appropriate costs for land preparation, planting, and pruning activities. There were few respondents who use labour for doing these activities whereby land preparation costs TZS 111,150 per ha at Kibengu and TZS 74,100 per ha at Ilogombe. According to the respondents land preparation here meant slashing large grasses and shrubs and this occurs rarely; most of the time they plant trees in previous crop cultivated land where there is no need for clearance.

Tree transplanting costs were also predicted by using the information from the few respondents who use labour force for planting activities likewise in the case of pruning. Transplanting cost was TZS 49,400 per ha and pruning costs was TZS 74,100 per ha in the two study villages. The costs for land preparation, planting, pruning, and thinning at Sao Hill Forest Plantation (SHFP) were 46,728, 62,304, 72,688, and 72,688 TZS/ha, respectively, for 9, 12, 14, and 14 man days, respectively. This is equal to the payment of TZS 5,192 per man day. Pruning and thinning activities at SHFP were normally carried out two times per rotation. On the basis of these results, small scale farmers use more costs for land preparation than the SHFP, but lower costs in pruning and no thinning costs.

The most preferred tree species was Pinus patula for business purposes. Some Eucalyptus spp. and Acacia meansii were observed in some areas in the study area but were not mentioned by the respondents. Planting spacing was $2 \mathrm{~m} \times$ $2 \mathrm{~m}, 2.5 \mathrm{~m} \times 2.5 \mathrm{~m}$, and $3 \mathrm{~m} \times 3 \mathrm{~m}$ but many used $2.5 \mathrm{~m} \times 2.5 \mathrm{~m}$. The rotation age of Pinus patula in the study area was between 5 and 15 years, with the average of 9 years. The selling price for trees was between TZS 2500 and TZS 10,000 per tree where
$69 \%$ of the respondents sell their trees for TZS 5000 per tree. The trees were sold for timber purposes and the farmers used to sell standing trees where buyers cut them into saw logs and then lumber at their own costs.

The main source of tree seedlings was local; they collect seeds from old Pinus patula plantation for nursery establishment. Most farmers used to establish their own tree nurseries to get enough seedlings for own use and any excess is sold to other villagers who did not manage to have own nurseries. The cost per seedling was between 60 and 100 Tanzania shillings. Therefore for easy calculation of the seedling costs, we made an assumption that all the respondents were buying seedlings rather than preparing for themselves. We also observed that the prevailing price was TZS 100 per seedling. Due to lack of adequate financial resource for buying polythene tubes, some of the households prepared their own traditional nurseries known as Swaziland.

The profitability of tree planting was determined by calculating the NPV at a discount rate of $10 \%$ and time horizon of 20 years assuming that REDD+ will be implemented for 20 years as from 2012. The results of analysis show that the average NPV of woodlots in the two study villages was TZS 5,199,647.21/ha (Table 2).

3.4. The Aboveground Carbon Stock of Idewa Forest Reserve. The total amount of carbon at Idewa Forest Reserve (IFR) was estimated to be $39.23 \mathrm{tC} / \mathrm{ha}$ which is equivalent to $143.97 \mathrm{tCO}_{2} \mathrm{e} / \mathrm{ha}$. Munishi and Shear [20] reported the above ground carbon of $427 \pm 14$ and $318 \pm 8 \mathrm{tC} /$ ha for the Usambaras and Ulugurus, respectively. The authors concluded that their estimates were just approximations and a preliminary contribution to the assessment of such potential in the Eastern Arc Mountain forests and recommended further studies to improve these estimates. Brown et al. [26] concluded that only about $6 \%$ of mature forests in Tropical Asia had biomass less than $500 \mathrm{t} / \mathrm{ha}\left(245 \mathrm{tha}^{-1} \mathrm{C}\right)$ while more than $61 \%$ of the forests had biomass less than $250 \mathrm{tha}^{-1}\left(122.5 \mathrm{tha}^{-1} \mathrm{C}\right)$. This 
TABLE 3: Quantity of aboveground carbon stock and profitability based on prices reported by various authors.

\begin{tabular}{lcccc}
\hline Unit price $\left(\$ / \mathrm{tCO}_{2} \mathrm{e}\right)$ & Author(s) & Carbon $(\mathrm{tC} / \mathrm{ha})$ at IFR & tCO $\mathrm{e} / \mathrm{ha}$ at IFR & NPV $(\$ / \mathrm{ha})$ \\
\hline 5 & Nordhaus [9] & 39.23 & 143.97 & 719.871 \\
20 & Fankhauser [10] & 39.23 & 143.97 & 2879.48 \\
6 & Sedjo et al. [11] & 39.23 & 143.97 & 863.84 \\
$36.5-44.13$ & Healey et al. [12] & 39.23 & 143.97 & $5255.06-6353.58$ \\
$12-59$ & Tol [13] & 39.23 & 143.97 & $1727.69-8494.47$ \\
178 & Jakob et al. [14] & 39.23 & 143.97 & 25627.39 \\
$18-90$ & Stern [15] & 39.23 & 143.97 & $2591.53-12957.67$ \\
29 & Bloomberg News [16] & 39.23 & 143.97 & 4175.25 \\
150 & Maibach et al. [17] & 39.23 & 143.97 & 21596.12 \\
$20-50$ & Litman [18] & 39.23 & 143.97 & $2879.48-7198.705$ \\
\hline
\end{tabular}

Source: field data (2012).

study carbon results seem to be very low as compared to other montane forests as presented above. This difference may be due to difference in geographical location, soil characteristics, forest structure, and the research designs between these studies. The results show that most of the people adjacent to IFR have their own woodlots which serve them for timber, firewood, and cash flow. They are also aware of the importance of the forest as a source of rainfall for their rain dependent agricultural crops. The value of the forest in terms of carbon when multiplied by various prices as proposed by different authors is presented in Table 3.

3.5. Profitability of Agriculture and Woodlots in Comparison with the REDD+ Incentives. The profitability of agriculture and woodlots in comparison with REDD+ incentives was determined by calculating the NPV for agriculture and woodlots and the total amount of cash flow of $\mathrm{CO}_{2}$ e per ha. Results show that the NPV for agriculture and woodlots were USD 2958.52 and USD 3272.94 per ha per year, respectively. The cash flow per ha of $\mathrm{tCO}_{2} \mathrm{e}$ was depending on which unit price per $\mathrm{tCO}_{2}$ e was adopted. Based on Nordhaus [9] unit price, the NPV was USD 719.87/ha and when based on Jakob et al. [14] unit price, the NPV was USD 25627.39/ha (Table 4). These two authors show the minimum and maximum unit prices of carbon, respectively. In the MNRT and UN-REDD+ [27] the Jane Goodall Kigoma Project has revealed that the NPV for natural forest amounts at US\$ 924/ha, while shifting cultivation is the most profitable business in this region with a NPV of US\$2,806/ha. This indicates that the avoidance of converting natural forest to shifting cultivation will comprise the highest opportunity costs. Tanzania Forest Conservation Group (TFCG) Kilosa project also estimated the opportunity costs of REDD+ to be $12.1 \mathrm{USD} / \mathrm{tCO}_{2}$ e due to unsustainable charcoal production and $8.8 \mathrm{USD} / \mathrm{tCO}_{2} \mathrm{e}$ due to agriculture (shifting cultivation) [27].

Results of this study show that, for the communities in the study area to get benefits from land use change for REDD+ implementation, the unit price of carbon should start at USD $23 \mathrm{USD} / \mathrm{tCO}_{2} \mathrm{e}$ ) and above. This is because it will provide benefits which equal the maximum profit when land is used for woodlot which is more beneficial than agriculture based on the considered components of production. The unit prices of
USD 5 and USD $6 \mathrm{USD} / \mathrm{tCO}_{2} \mathrm{e}$ ) result in low NPV compared to the alternative land uses. Apart from this compensation, REDD+ implementers should consider the material needs of these communities such as fuel wood and transportation costs of food from other areas. According to Bond et al [28], two programmes in Latin America-Pimampiro (Ecuador) and the PSA-H (Mexico) - pay between USD 6-12 and USD $27-£ 6$ per hectare per annum, respectively. In Vietnam, the government pays between USD 3 and USD 6.5 per hectare per annum, although this isconsidered to be low compared with alternative land uses [29]. If the opportunity costs of REDD+ are not taken into account, its implementation may be effective at the beginning but the effectiveness will not be sustainable especially when the communities become aware that they are losing more than what they are gaining. The opportunity costs of agriculture and woodlots in the study area are as shown in Table 4.

\section{Conclusions}

This study concludes that the economic value of alternative land uses depends on the type of the land use and the requirements for production. Also the aboveground carbon stock of the montane forests along the Eastern Arc Mountains varies from one location to another. Moreover, the profitability of any land use is determined by inputs used for production and the selling price of the products which indicate the opportunity costs incurred when implementing REDD+. This implies that there is no general price per $\mathrm{tCO}_{2} \mathrm{e}$, instead it depends on REDD+ opportunity cost of a particular place when compared with alternative land uses. Therefore careful examination of the costs involved to adopt REDD+ is very important for the initiative to be effective and sustainable. The REDD+ payments should cover the opportunity costs incurred by communities; otherwise its implementation may not be sustainable.

Based on findings and conclusion of this study, the following are some of recommendations for success of REDD+ to the communities of Mufindi District.

(i) Opportunity costs of REDD+ to different communities should be used to guide decision making on unit prices of carbon as it varies from place to place 
TABLE 4: Opportunity costs of REDD+ on agriculture and woodlot establishments for different carbon unit prices.

\begin{tabular}{lccc}
\hline Author(s) & Unit price $\left(\$ / \mathrm{tCO}_{2} \mathrm{e}\right)$ & Agriculture & Woodlot \\
\hline Nordhaus [9] & 5 & 2238.65 & 2553.07 \\
Fankhauser [10] & 20 & 79.04 & 393.46 \\
Sedjo et al. [11] & 6 & 2094.68 & 2409.10 \\
Healey et al. [12] & $36.5-44.13$ & $-2296.54-(-3395.06)$ & $-1982.12-(-3080.64)$ \\
Tol [13] & $12-59$ & $1230.83-(-5535.95)$ & $1545.25-(-5221.53)$ \\
Jakob et al. [14] & 178 & -22668.87 & $(-22354.45)$ \\
Stern [15] & $18-90$ & $366.99-(-9999.15)$ & $681.41-(-9684.73)$ \\
Bloomberg News [16] & 29 & $(-1216.73)$ & $(-902.31)$ \\
Maibach et al. [17] & 150 & $(-18637.60)$ & $(-18323.18)$ \\
Litman [18] & $20-50$ & $79.04-(-4240.19)$ & $393.46-(-3925.77)$ \\
\hline
\end{tabular}

Source: field data (2012).

depending on the alternative land uses available and production techniques.

(ii) More studies are needed in the study area to identify the more accurate opportunity costs of REDD+ to the communities by involving all alternative land uses and measuring the size of their farms.

(iii) Further studies are needed to determine the carbon below ground including roots, soil, and litter so as to obtain the total amount of carbon including development of carbon model for IFR to simplify remeasurements in future times.

\section{Conflict of Interests}

The authors declare that there is no conflict of interests regarding the publication of this paper.

\section{Acknowledgments}

First of all, one of the authors thanks the Almighty God for his grace and mercy which kept them up to this moment. The author would like to express their sincere thanks to the Climate Change Impact Adaptation and Mitigation Program (CCIAM) for the financial support in this study. Appreciations are also extended to the Mufindi District Council for allowing them to conduct our research in the district without forgetting the District Forest Officer (DFO) Mr. Shabani Adha for his assistance in obtaining important documents, accommodation, and organizing transport to the study site and indeed introducing them to the village leaders. They would also like to thank all the village government leaders for introducing them to the villagers. Furthermore they would like to thank all respondents for their cooperation. Extraordinary thanks should go to their beloved families for their tireless encouragement throughout the period of the study despite the hardships they faced during their absence. Their ethical support is extremely appreciated.

\section{References}

[1] A. Angelsen and S. Wertz-Kanounnikoff, "What are the key design issues for REDD and the criteria for assessing options?" in Moving Ahead with REDD: Issues, Options and Implications, A. Angelsen, Ed., CIFOR, Bogor, Indonesia, 2008.

[2] A. Angelsen, Realising REDD+: National Strategy and Policy Options, CIFOR, Bogor, Indonesia, 2009.

[3] J. Gurung, K. Giri, A. B. Setjowati, and E. Lebow, "Gender and REDD+: An Asia Regional Analysis," 2010.

[4] World Bank Institute (WBI), "New Training Manual and Workshops. Estimating the Opportunity Costs of REDD+," 2011, http://wbi.worldbank.org/wbi/.

[5] FoEI (Friends of the Earth International), REDD Myths: A Critical Review of Proposed Mechanisms to Reduce Emissions from Deforestation and Degradation in Developing Countries, FoEI, Amsterdam, The Netherlands, 2008.

[6] URT, National Forest Policy, Ministry of Natural Resources and Tourism, Dar Es Salaam, Tanzania, 1998.

[7] URT, The Forest Act No. 14. United Republic of Tanzania, Ministry of Natural Resources and Tourism, Dar es Salaam, Tanzania, 2002.

[8] B. Swallow, M. van Noordwijk, S. Dewi et al., "Opportunities for Avoided Deforestation with Sustainable Benefits," An Interim Report by the ASB Partnership For the Tropical Forest Margins, ASB Partnership for the Tropical Forest Margins, Nairobi, Kenya, The Forests Dialogue. 2010. TFD Review: Investing in REDD-plus, Consensus Recommendations on Frameworks for the Financing and Implementation of REDD-plus, TFD Publication Number 1, The Forests Dialogue, New Haven, 2007.

[9] W. D. Nordhaus, "Rolling the "DICE": an optimal transition path for controlling greenhouse gases," Resource and Energy Economics, vol. 15, no. 1, pp. 27-50, 1993.

[10] S. Fankhauser, Valuing Climate Change, Earthscan, London, UK, 1995.

[11] R. A. Sedjo and E. Ley, "The potential role of large-scale forestry in Argentina," in Climate Change Mitigation and European Land Use Policies, W. N. Adger, D. Pettenella, and M. Whitby, Eds., pp. 255-268, CAB International, Wallingford, UK, 1997.

[12] J. R. Healey, C. Price, and J. Tay, "The cost of carbon retention by reduced impact logging," Forest Ecology and Management, vol. 139, no. 1-3, pp. 237-255, 2000.

[13] R. S. J. Tol, "The marginal damage costs of carbon dioxide emissions: an assessment of the uncertainties," Energy Policy, vol. 33, no. 16, pp. 2064-2074, 2005. 
[14] A. Jakob, J. L. Craig, and G. Fisher, "Transport cost analysis: a case study of the total costs of private and public transport in Auckland," Environmental Science and Policy, vol. 9, no. 1, pp. 55-66, 2006.

[15] N. D. William, "The "Stern Review" on the Economics of Climate Change," Working Paper 12741, The National Bureau of Economic Research, 2006, http://booksily.net/pdf/stern-reviewon-the-economics-of-climate-change.

[16] Bloomberg News, "Price difference between EU and UN carbon credits offers huge profit opportunity," International Herald Tribune, 2007, http://topics.nytimes.com/top/opinion/series/ turning_points_2014/.

[17] M. Maibach, C. Schreyer, D. Sutter et al., "Handbook on estimation of external cost in transport sector," CE Delft, 2008, http://ec.europa.eu/transport/sustainable/doc/2008costshandbook.pdf.

[18] T. A. Litman, "Climate change emission valuation for transportation economic analysis," The Report, Victoria Transport Policy Institute, 2009, http://www.vtpi.org/ghg_valuation.pdf.

[19] D. K. Bailey, Methods of Social Research, Macmillan Publisher, London, UK, 1994.

[20] P. K. T. Munishi and T. H. Shear, "Carbon storage in afromontane rain forests of the eastern arc mountains of tanzania: Their net contribution to atmospheric carbon," Journal of Tropical Forest Science, vol. 16, no. 1, pp. 78-93, 2004.

[21] P. K. T. Munishi, S. Mringi, D. D. Shirima, and S. K. Linda, “The role of the Miombo Woodlands of the Southern Highlands of Tanzania as carbon sinks," Journal of Ecology and the Natural Environment, vol. 2, no. 12, pp. 261-269, 2010.

[22] R. E. Malimbwi, "Forest extent and ownership in Tanzania," A Consultancy Report Requested By Tanzania Conservation and Management Project (TCMP), 2001.

[23] D. White and P. Minang, "Estimating the opportunity costs of REDD+. A training manual," 2011, http://www.forestcarbonpartnership.org/.

[24] R. Mnenwa and E. Maliti, "A comparative analysis of poverty incidence in farming systems of Tanzania," Spacial Paper 10/4, REPOA, Dar es Salaam, Tanzania, 2010.

[25] J. A. Ngailo, F. B. S. Kaihura, F. Baijukya, and B. J. Kiwambo, "Land use changes and their impact on agricultural biodiversity in Arumeru, Tanzania," 2001.

[26] S. Brown, A. J. R. Gillespie, and A. E. Lugo, "Biomass of tropical forests of South and Southeast Asia," Canadian Journal of Forest Research, vol. 21, no. 1, pp. 111-117, 1991.

[27] MNRT and UN-REDD+, Estimating cost Elements of REDD+ in Tanzania, 2012.

[28] I. Bond, M. Grieg-Gran, S. Wertz-Kanounnikoff, P. Hazlewood, S. Wunder, and A. Angelsen, Incentives to Sustain Forest Ecosystem Services, International Institute for Environment and Development (IIED), London, UK, A Review and Lessons for REDD, 2009.

[29] B. M. Liss, "Development and application of a pilot policy on Payment for Environmental Services (PES) in Da River Basin, Son La Province," Consultant Report to the VietnameseGerman Forestry Programme, International Consultancy Services, Landsberg/Lech, Germany, 2008. 

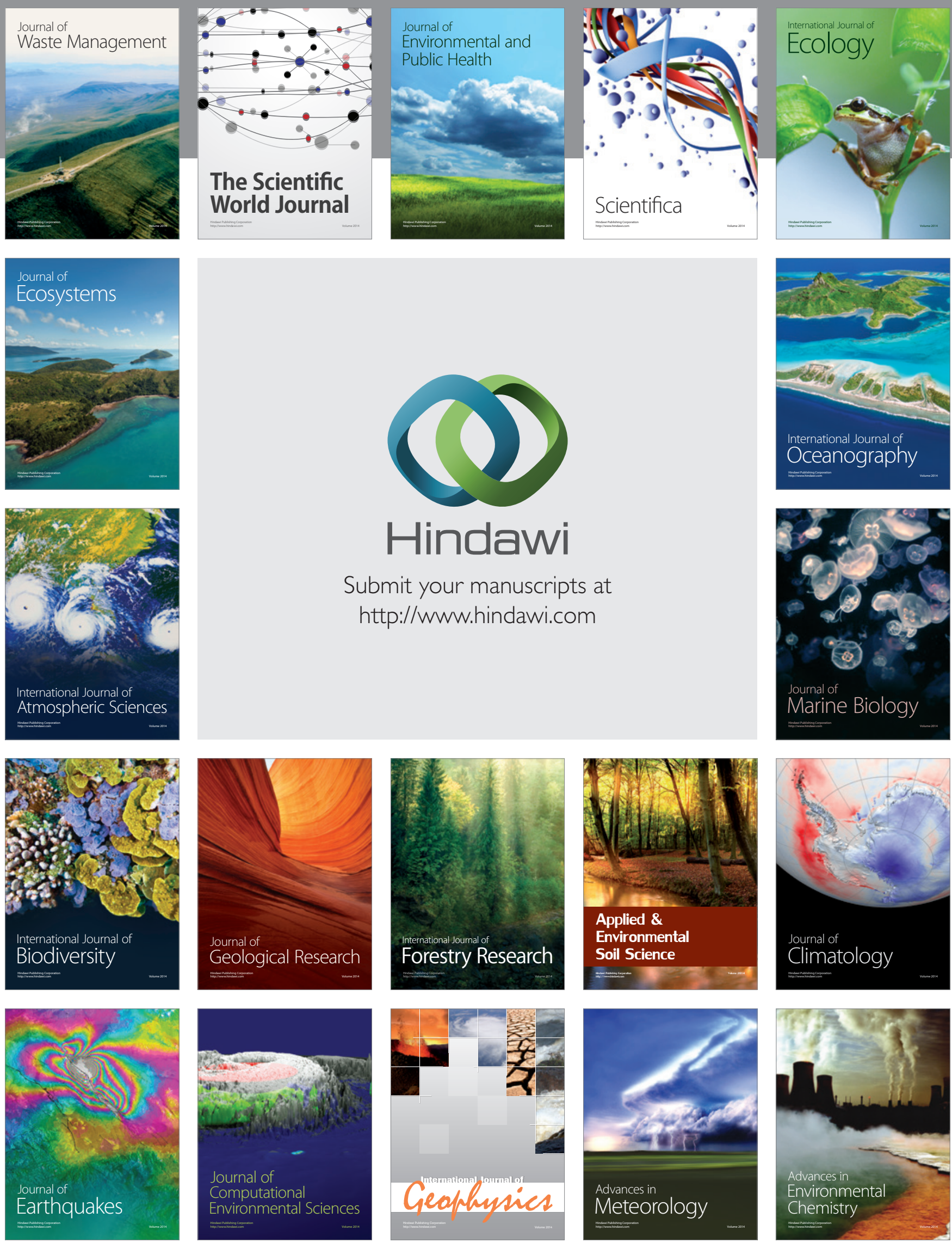